\title{
Geological factors of the Guadalajara landscapes (Central Spain) and their relevance to landscape studies
}

\author{
A. García-Quintana ${ }^{a}$, J.F. García-Hidalgo ${ }^{\text {b,* }}$, J.F. Martin-Duque ${ }^{c}$, \\ J. Pedraza ${ }^{c}$, J.A. González-Martin ${ }^{\mathrm{d}}$ \\ a Dpto. Estratigrafía, Inst. Geol. Económica, Fac. C.C. Geológicas, U.C.M., 28040 Madrid, Spain \\ b Dpto. Geología, Fac. C.C. Ambientales, Univ. de Alcalá, 28871 Alcalá de Henares, Madrid, Spain \\ c Dpto. Geodinámica, Fac. C.C. Geológicas, U.C.M., 28040 Madrid, Spain \\ d Dpto. Geografia, Fac. Filosofia y Letras, Univ. Autónoma de Madrid, 28049, Madrid, Spain
}

\begin{abstract}
The landscapes of a territory are the consequence of its history; overlapped geological, vegetable and cultural histories usually exist on a landscape. At the Mediterranean domain, however, a translucent vegetation exists, and its history is closely related to the geologic and cultural histories, because low-technology agricultural uses on a different hardness rock background control vegetation. Thus, in areas like the Guadalajara province, the geologic composition and the human activities can be considered the primary conditions for landscape configuration. Both condition the typologies, distribution and relative importance of the geotic, biotic and anthropogenic components of landscapes. A complex network of interrelations among all them exists but, in the base of which lie the geology of the territory, included relief, because it has a more independent influence since man cannot modify the geologic factors; such as the colour of the rocks, the size and distribution of rock bodies, the palaeogeographic domains and the tectonic structure all which control landscape development and configuration. Moreover, geology influences conditions and even limit, the presence, typologies and development of the biotic and anthropogenic elements. These factors also have a major relevance for environmental management, educational and economic policy, and, in some cases, for environmental impact assessment.
\end{abstract}

Keywords: Geology; Landscape; Mediterranean domain

\section{Introduction: the ambiguity in the landscape term}

Landscape studies of a territory should always begin with the identification of its geologic factors,

\footnotetext{
* Corresponding author. Tel.: +34-91-885-5097; fax: +34-91-885-5090.

E-mail addresses: alvaro.garcia@geo.ucm.es(A. García-Quintana), jose.garciahidalgo@uah.es (J.F. García-Hidalgo), josefco@geo.ucm.es (J.F. Martin-Duque), javierp@geo.ucm.es (J. Pedraza), juantonio.gonzalez@uam.es (J.A. González-Martin).
}

which allow to perceive, to understand and to value better the entire landscape, their components and each one of their properties.

Landscape is actually one of the important environmental and cultural issues of society. A broad socialisation of landscape took place in the last decade favoured by the economic and cultural development of society. In developed societies, the change from primary/secondary-based economies to tertiary-based ones led from considerating the territory as a resource to considerating it as a patrimony. This enhanced 
the development of the landscape as an asset. The result is a great expansion of the landscape concept and a widening of the use of the landscape term in technical and academic fields, far from the original artistic, gardens and literary fields (Rougerie and Beroutchachvili, 1991; Bolós et al., 1992).

Landscape is the perception of a territory as a cultural, scientific and patrimonial property, with mainly aesthetic, and more secondarily environmental and historical value. The relationship of landscape concept it is so close with their physical support, that "landscape" is also denominated to the perceived territory in the scientific and technician's fields. Ecology and geography also include in the landscape concept dynamic factors that only are, generally, less or occasionally visually perceptible. All that generates a great complexity in the study of the landscape and in its terminology.

There is a considerable disparity in landscape concepts, and, as a result, there also exists a lack of standardization of analytical methodologies among landscape scientists "caused by the ambiguity of the phenomenon of landscape, which originates from the developed analytical systems of the brain" (Aoki, 1999). Landscape concept rests on three bases, which have been picked up in the etymology of the word "landscape" in European languages. The first and fundamental is the territory (land-, in English and German languages; pais-, in the Latin languages), since there is not landscape without territory (Fig. 1).

Second, is the deliberate perception (Fig. 1), since there is not landscape if territory is not intellectually investigated. Landscape affects and is affected by human perception, cognition and values (Nassauer,

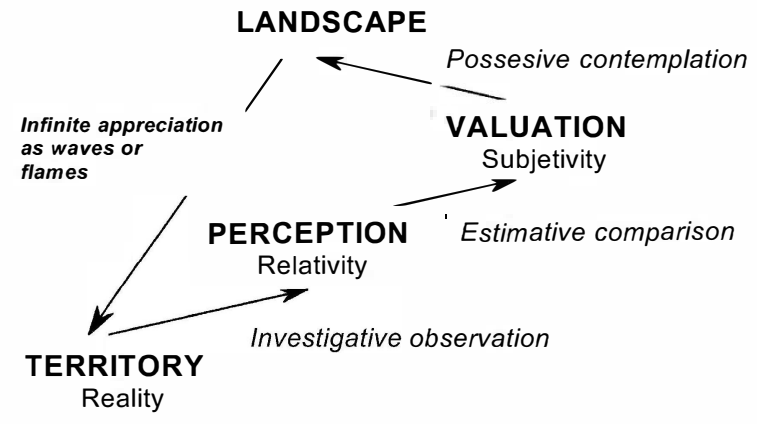

Fig. 1. Intellectual itinerary from territory to landscape.
1995). The landscape is thus a perceived segment of the earth's surface, which can be redefined as "a way of seeing" rather than a scene or an image (Cosgrove, 1998). It is necessary, however, that it is made with an integrative focus that builds a group with all the identified individualities. Landscapes are both materially and perceptually constructed (Terkenli, 2001) (Fig. 1).

Thirdly, it is a positive valuation, because there is not landscape if this deliberate and integrative perception of the territory does not generate in the observer any type of emotion (Fig. 1). Landscape then is "a visible expression of the humanised environment perceived mainly through sensory, and particularly visual, as well as cognitive processes; a medium and an outcome of human action and perception" (Terkenli, 2001). These last two requirements of the landscape concept (action, integration, group and valuation) appear to be reflected in the European languages by the uses of the suffixes of the word "landscape" (-chap, in Hollander that originate to the English suffix -ship; -scape/-cape in English; -aje in Spanish that is also used in action terms like "abordaje" - boarding - and in group terms as "cordaje"_cordage, etc.).

If landscape is understood as a patrimony, both the visitors and planners experience the quality of countryside landscape mainly through visual exploration (Fig. 1); the visual landscape so explored is clearly linked to landscape structure. In this visual sense, a territory is characterised by the features of their visual space (big, small, lengthened, dispersed, subcircular, guided, etc.), by their elements (hills, ravines, plains, forests, etc.) that contribute with forms, colours and textures, and by their boundaries. Unfortunately, neither of the terms that have been proposed in order to denominate the material support of the visual landscape, such as "geosystem" (Sochava, 1972), "geofacies" (Bertrand and Berutchachvili, 1978), etc., have not had a wide acceptance. Visual spaces are then main components of landscapes but, at the same time, they are the most relative and abstract, also originating another ambiguity for the term landscape. The same area (landscape-territory) changes its image (landscape-image) just by changing the observation position. All the images of a region or a specific area, however, have a common essence (landscape-comprehension). This is the main concept of landscape in which this work is based. 


\section{Components and factors in landscapes}

There are three types of genetic components and factors in landscapes that are causal and spatially related to each other: geotic, anthropic and biotic.

Landform analysis of geotic components can be approached with several different emphases; but these landforms are almost always the result of a complex mixture of processes interacting on the landscape. Most of landforms were formed primarily by differential erosion of rocks, acting on structures produced by endogenic processes, under several climatic processes. Except volcanic reliefs and eolian dunefields that are mainly formed due to rock or sediment accumulation, the rest of landforms are formed by erosion of the existent rocks for water and ice. Some areas of the terrestrial surface have a homogeneous rocky composition and then erosive processes originate homogeneous or, at least, isoropic morphologies. Most of the terrestrial surface, however, is composed of rock bodies both with different resistance to erosion and with different volume and spatial disposition. These elements influence, in a very important way, the morphologies of a territory. Thus, each part of the land surface is the end product of an evolution governed by: (a) parent geological material, that is lithology, or materials to erode; (b) tectonic structure, which controls the 3-D distribution of the different rock bodies having different resistance to erosion; and (c) climatic evolution, which controls the type of erosive processes (arid, fluvial or glaciers) (Bloom, 1969; Thombury, 1969; Wright, 1972; Burbank and Printer, 1999).

On the other hand, rural landscapes in developed countries (as in many other countries) are "semi-natural" landscapes which records the combined effects of human activity superimposed upon a geological and vegetation background. These landscapes are mainly anthropogenic, produced through centuries of land use (deforestation, reforestation, clearings, extensive grazing, etc.). So, these landscapes record the relationships of man (anthropogenic), vegetation (biotic), rock (geotic) factors. Some of these factors are scale-dependent, and their relative importance in a landscape depends on the observational scale. Generally, geotic factors, such as the scenery, are usually longer and wider, having much importance in landscape perception at greater scales. On the contrary, anthropogenic elements usually have the smallest dimensions, and then its importance in the landscape is inversely proportional to the observation scale.

Vegetation lies in an intermediate position, because plant communities have very variable extent, and then its importance in the landscape is not so dependent of the observation scale. There are three different situations: (a) "vegetation dominated" landscapes, where the vegetable cover, both natural or anthropogenic (agricultural landscapes) and thicker soils do not allow for any rock cropping out, or the outcrops are scarce and isolated; as occur in the Atlantic or tropical rain forests; (b) "geologic" landscapes, lacking any vegetable cover or soils, as the warm and cold deserts, where rock presence is almost exclusive; and (c) "intermediate" landscapes, where the agriculture and extensive cattle grazing under a regime of scarce rainfall, produce a balanced situation of rocks and vegetation in the landscape, with thin soils which are frequently removed or eroded, as in most of the Mediterranean areas. In this case, plant cover is not visually opaque and due to its low-density acts like a translucent cover that allows participating to the colors, textures and many rock elements in the landscape.

Besides geotic, anthropic and biotic components, in the visual landscapes the "space" has as much importance as other genetic components. Forms, dimensions and distribution both of the prominent elements, i.e. hills, mountains or mountain ranges, and the areas separating those elements, i.e. plains and valleys, and their similarities and differences as well, influence notably in the characteristics of the landscapes. The configuration of the visual space of a landscape is denominated "scenery" or "structure" and the orographic structure is the most important control of these space factors in the case of the rural and "semi-natural" Mediterranean landscapes.

In the scenery, what shapes a landscape different as a place is primarily its distinctive geology. Geology (rock type and structure) and geological processes (erosion and sedimentation) underpin the development of landscape scenery and the overall "character" which describes the totality of a range of landscape features, including soils, ecology, agriculture, archaeology and features of cultural history and developed in these distinct physical settings (Knight, 2000). The relief of an area, and also its absence, is the unavoidable 
consequence of its geological history, even though the rock groups do not seem to participate directly in their landscapes with their colors and singular forms. Therefore, geology is almost exclusively responsible for a region's relief and, as a consequence, mainly dominates the structure of the landscape scenery and their regional landforms. The relief is, then, an end product for geology; but in landscape studies, with its various biologic and economic phases, it is just the point of departure (Fenneman, 1916).

Thus, in the "geologic" and "intermediate" landscapes the interpretation of a territory should always start with identification of those geological factors, what makes us better understand, describe, classify and value their visual, semi-natural landscapes. The following description focuses first on several aspects of the lithological and structural factors of landscapes; and, secondly, we also emphasize the relationships of anthropogenic, biotic and geotic factors on the landscape, with an application to the landscapes of Guadalajara province. The enormous variability of Guadalajara landscapes is significant due to their highly irregular orography, geological differences and climatic diversity that are reflected in the variety of their translucent vegetable cover

\section{Geological setting of the Guadalajara province}

Guadalajara (Castilla, La Mancha Community) is a province that occupies more than $12,000 \mathrm{~km}^{2}$ at the cen of Spain (Fig. 2, left). It is a territory with both an uneven orography and a considerable relief (600-2.300 m.a.s.1.). It has a continental Mediterranean climate, with many cold days (minimum historical temperature is $-27^{\circ} \mathrm{C}$ ), and frequent windy days. Although the medieval cities were very important (Atienza, Molina de Aragón, Sigüenza, etc.), later the province was in a marginal location from areas of industrial and demographic growth. So, presently the traditional rural, semi-natural landscapes prevail In Guadala jara, during the autumn and the winter, the low inclination of the sun stands out the shades of the relief, and great intensity and beauty landscapes can be observed. Besides, in the cold, sunny and windy days, the amosphere is clean providing visibility up to $100 \mathrm{~km}$.
The province is composed of three regions (Fig. 2, left): (a) the Central System, an Alpine reactivation of Hercynian basement, which presently is a mountainous area with maximum heights of 2.500 m.a.s.1 (1 in Fig. 2), with a fringe of Alpine Mesozoic rocks (9 in Fig. 2); (b) The Iberian Ranges, a Mesozoic intracontinental basin, folded during Alpine Orogeny, with lower heights than the Central System but with a more complex orographic distribution (2-5 and 8 , in Fig. 2); (c) The Tajo Basin, a Cenozoic intracontinental basin, marginal to both mountainous areas that was an active sedimentary basin until Pliocene times and that later on it has suffered a strong entrenchment of the Quaternary fluvial network (mainly from the Tajo river system, from which it takes its name), because of that it shows a lesser relief than the previous domains, but far away of being a simple plain (6 and 7 in Fig. 2), with outcrops of folded Mesozoic rocks (Sierra of Altomira, 10 in Fig. 2). Thus, in this province there is: (a) plutonic, metamorphic and sedimentary rocks; (b) areas with complex Hercynian structures, with Alpine structures, and non-folded Cenozoic regions; (c) diverse climatic erosive patterns; and (d) areas covered with thick surficial deposits alternating with areas lacking those deposits, where underlying rocks crops widely out, forming and intensely participating in the landscape configuration.

Such geologic and orography diversity, as well as climatic, is reflected in the variety of their vegetable cover, and their historical and cultural villages and cities. There are from alpine-type coniferous forests to steppes of aromatic, and from green grasslands with cattle raising, to cereal steppes with an intense yellow colour in summer and autumn. There are "black villages" in areas of Paleozoic slates of the Central System (e.g. Valverde de los Arroyos; Fig. 2), "red towns" in areas of the Iberian Ranges, where the only noble rock for building was the Buntsandstein red sandstones (e.g. Sigüenza; Fig. 2); "white villages" in areas with Jurassic calcareous strata (e.g. Anquela del Pedregal; Fig. 2); and "ochre villages" adobe- or brick-built within the brown argillaceous areas in the Tertiary Tajo Basin (e.g. Pastrana; Fig. 2). In the last years, this archaeological and cultural landscape has started to be valued and correct measurements have been applied to the impacts caused by concrete and industrial brick building 

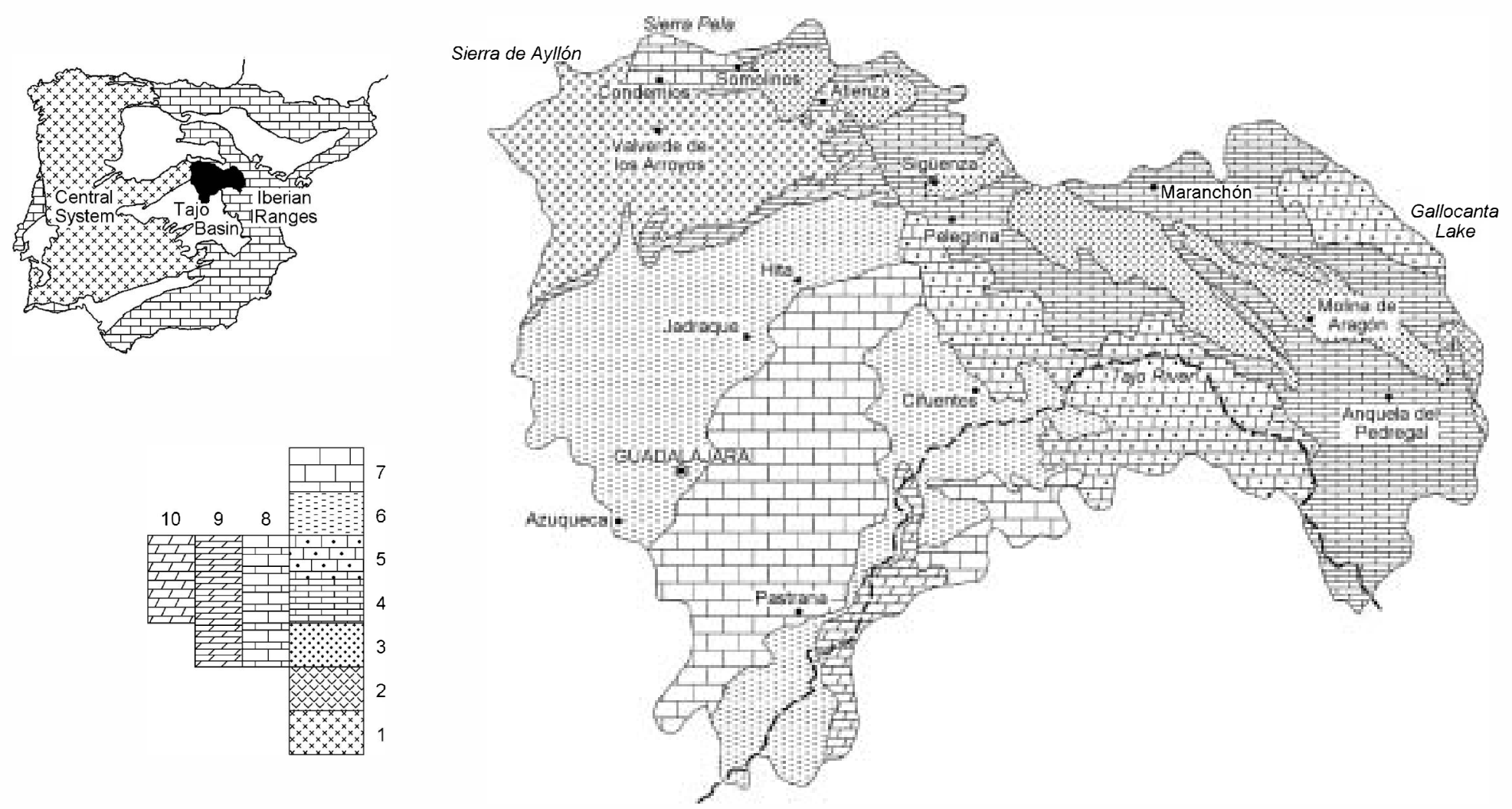

Fig. 2. Geological domains of Guadalajara province (left, geological location and physiographic regions within the Iberian Peninsula): (1) Hercynian rocks of the Central System; (2: Hercynian basement of the Iberian Ranges; (3) Permian and Triassic mainly with cuesta structures; (4) cuestas or complex folded Jurassic calcareous and marls Formations; (5) tabular and strongly folded areas in Cretaceous limestones; (6) horizontal Cenozoic siliciclastic series; (7) horizontal Upper Neogene calcareous series; (8) tabular Cretaceous overlying Triassic; (9) thin Triassic and Cretaceous of the Central System; (10) strongly folded Cretaceous of Sierra of Altomira. Localities mentioned in text are also shown. 


\section{The influence of lithology on the Guadalajara landscapes}

Rock composition influences landscape due to four rock properties: the colour, the resistance to erosion, the size of the rock bodies and the orientation of these rock bodies (Fig. 3). This relationship between lithological composition of a territory and their landscapes is especially certain in areas constituted by sedimentary and low-grade metamorphic rocks; meanwhile, in those areas composed of high-grade metamorphic rocks and plutonic rocks are the tectonic structure and the climate the main factors influencing their landscapes. These rock properties of a territory are the result of its geological history, and then, territories with a similar geological history present landscapes with a certain degree of homogeneity. On the contrary, territories composed of several geological domains, that is having different geological histories, also have very different landscapes. This is an evident fact in the landscapes of the Guadalajara province and explains both the differences between their own landscapes and the similarities of some of them with those of other areas of the Iberian Peninsula.
Rock resistance to erosion have been widely studied in the geological and geographical literature, and it is not treated here. On the contrary, we further discuss aspects like the colour, the 3-D distribution of rock bodies and the paleogeographic domains that had little attention in the literature.

\subsection{The colour of the rocks}

In unvegetated areas, or with a translucent vegetable cover, rocks contribute to the predominant colour of landscape. The dark colours of many "retamales" (broom) and "jarales" (rockrose) of the Sierra of Ayllón (Central System; Fig. 2) are due to the dark colour of the underlying Hercynian slates, where they rise up. Reddish and vine colours of some relief of the Atienza-Sigüenza region are due to the red Triassic sediments (Figs. 4 and 5), which in turn frequently support pinegroves. Whitish and greyish tones of most of the calcareous mesas and mountains at the east of Guadalajara (Iberian Ranges) are due to their calcareous substrate composed of Jurassic and Cretaceous limestones and dolostones (Figs. 4 and 5). Orange colours observed in many of landscapes

\begin{tabular}{|c|c|c|c|c|}
\hline $\begin{array}{l}\text { GEOLOGICAL } \\
\text { FIELDS }\end{array}$ & SCALE & \multicolumn{2}{|c|}{ GEOLOGY $\Rightarrow$ LANDSCAPES } & EXAMPLES \\
\hline \multirow[t]{2}{*}{ Paleogeography } & \multirow[t]{7}{*}{4} & Regional domains & $\begin{array}{l}\text { Physiographic } \\
\text { Regions }\end{array}$ & $\begin{array}{l}\text { Different stratigraphic succesions on different blocks of a } \\
\text { major fault (e.g., Sierra Pela Fault) }\end{array}$ \\
\hline & & $\begin{array}{c}\text { Morphology of } \\
\text { depositional sysizms }\end{array}$ & $\begin{array}{l}\text { Orographic } \\
\text { Structures }\end{array}$ & $\begin{array}{c}\text { Centrifugal fluvial netwoks on Tertiary alluvial fans (e.g., } \\
\text { ravines } \mathrm{N} \text { of } \mathrm{usges} \text { ) }\end{array}$ \\
\hline \multirow[t]{2}{*}{ Stratigraphy } & & $\begin{array}{l}\text { Rock bodies } \\
\text { dimensions }\end{array}$ & $\begin{array}{l}\text { Size of visual } \\
\text { spaces }\end{array}$ & $\begin{array}{l}\text { Wide valleys and extense visual corridors due to the } \\
\text { absence of calcareous Jurassic between Keuper and } \\
\text { Lower Cretaceous terrigenous facies ( e.g., Los } \\
\text { Condemios valey) }\end{array}$ \\
\hline & & Resistance to erosion & $\begin{array}{l}\text { Orographic } \\
\text { homogeneity or } \\
\text { heterogeneity }\end{array}$ & $\begin{array}{c}\text { Plainer plateaux on homogeneous lower Lias than on } \\
\text { heterogenous upper Lias (e.g., Molina de Aragón } \\
\text { plateaux) }\end{array}$ \\
\hline \multirow[t]{2}{*}{ Sedimentology } & & $\begin{array}{l}\text { Planar surfaces } \\
\text { (bedding, joints, } \\
\text { cleavage, etc.) }\end{array}$ & $\begin{array}{l}\text { Characteristic } \\
\text { small scale } \\
\text { landforms }\end{array}$ & "Tormos" in sandstones, "mallos" in conglomerates, etc. \\
\hline & & $\begin{array}{l}\text { Composition and } \\
\text { texture }\end{array}$ & Texture of forms & $\begin{array}{c}\text { Irregular forms due to dissolution on carbonates, rounded } \\
\text { forms due to granular disaggregation in sandstones and } \\
\text { granites, angular forms due to mechanical breakup in } \\
\text { slates, etc. }\end{array}$ \\
\hline Petrology & & Rock colors & Landscape colors & $\begin{array}{c}\text { Reddish landscapes on germanic Triassic, and grey-bluish } \\
\text { landscapes on Jurassic calcareous (e.g., valleys and } \\
\text { mesas near Sigionroal }\end{array}$ \\
\hline
\end{tabular}

Fig. 3. Relationships between the lithological composition of the territory and their landscapes. 


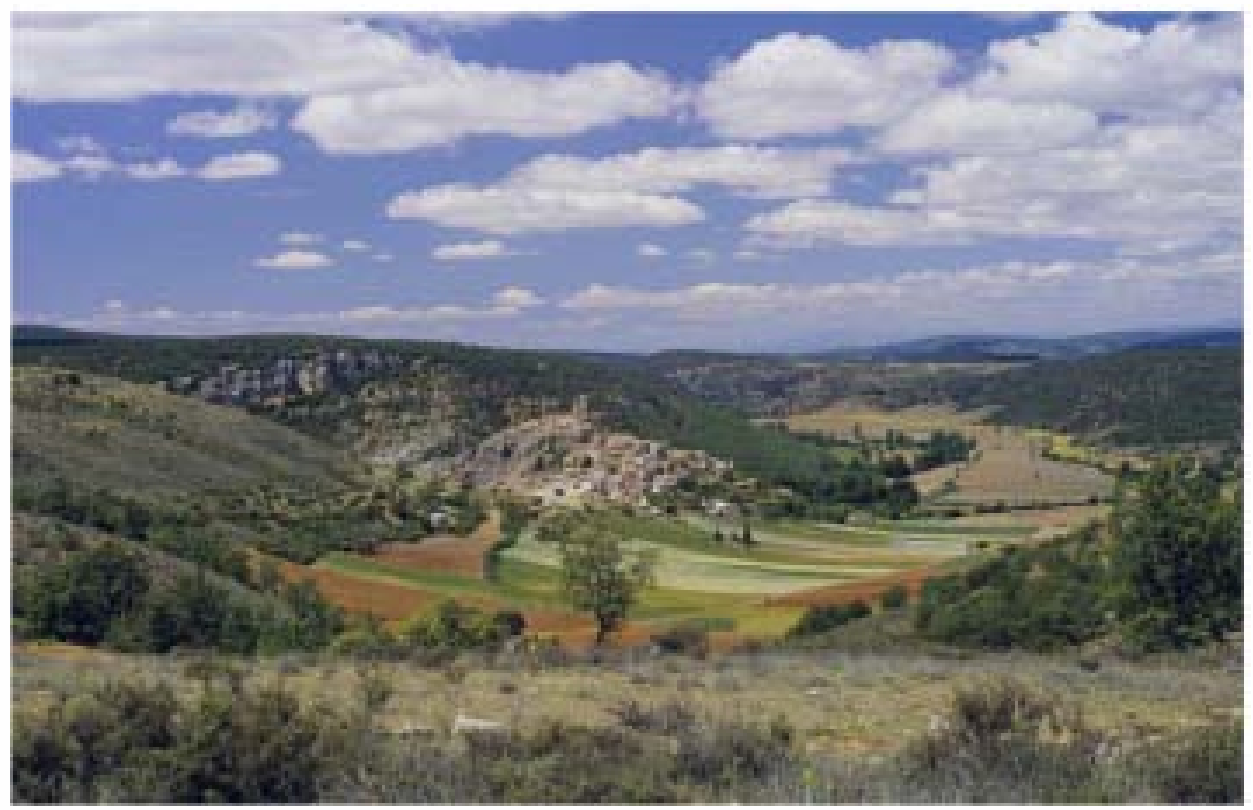

Fig. 4. View of Pelegrina valley (see Fig. 2 for location), developed on red Triassic (Keuper) mudstones and flanked by lower Jurassic dolostones. Red colours in the centre are due to the red Triassic mudstones, which are inconsistent rocks and can be ploughed. Jurassic dolostones are greyish, consistent rocks, and aromatic steppes for grazing and forests are developed.

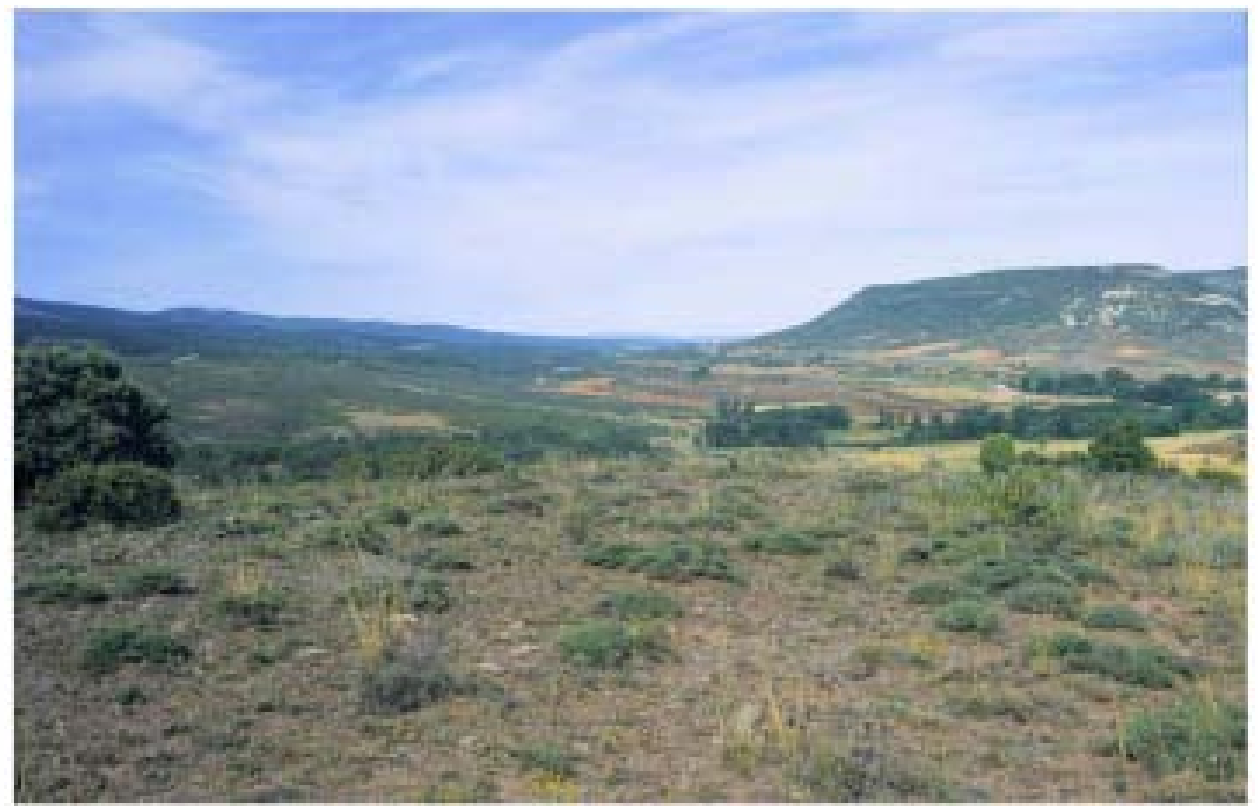

Fig. 5. View of Los Condemios valley (see Fig. 2 for location), developed on red Triassic mudstones and sandstones and white Lower Cretaceous sandstones and flanked by Paleozoic slates (left) and Cretaceous dolostones (right). Note: the influence of colours and the thickness of sedimentary succession on the valley sizes in the landscape. 
having a Paleogene substrate, usually located in the margins of the Iberian Ranges (mainly composed of calcareous sediments), are due to the highest concentration of decalcification clays in the postorogenic $\mathrm{Pa}-$ leogene deposits. In the margins of Neogene plateaux is characteristic the chromatic contrast, between the reddish and yellowish lower hillsides composed of sands and clays, with the whitish summits, which are mainly composed of lacustrine limestones. This fact has even been mimicked by some modern buildings, as in the city of Guadalajara (observable from the Aragón highway).

In most of the cases, and mainly in hard, consistent rocks, the landscape colour is the colour of the weathered surfaces, and then fresh, unaltered rocks (at quarries, renches of public works, etc.), stand clearly out in the landscape more than the spontaneous colours. Lichens also play an important role in the colour of the rocks, because on occasion they occupy a great part of the surface and some of them are specific of certain lithologies. Dark gray colours of some areas of the Alto Tajo calcareous rocks or the yellowish colours in the case of the Central System quartzites, have this origin

\subsection{The size and distribution of the rock bodies}

The rocks and their subsurface geometry are three-dimensional. Three-dimensional rock bodies have very dissimilar sizes and thickness, from some few meters to many kilometres; with a wide range in forms, from spherical (e.g. plutons, diapires) to tabular (e.g. lava flow, strata in sedimentary rocks); and with many possible three-dimensional orientations, in function of their tectonic structure, from unfolded areas to folded and faulted areas. These elements condition landforms and then visual landscapes in some areas.

In Guadalajara, there exist areas from wide lithologically homogeneous ones, to much more reduced ones with a great lithologic heterogeneity. In the first case, it originates as either very homogeneous landscapes, which can be wider landscapes if tectonic and erosive processes were homogeneous or ancient; or regularly uneven if tectonic and erosive processes were complex or recent. The observation scale has also a major influence in landscape perception; at greater scales landscapes are perceived as wider and homogeneous (Fig. 3). Lithologic and landscape homogeneity can be due to: (a) rock bodies of large dimensions (genetically related with extensive sedimentary basins or long and high mountainous belts, which are not present in Guadalajara), e.g. the broad Hercynian slate regions at the west of the Iberian Peninsula; (b) the coincidence in an area of several rock bodies having similar characteristics due to erosion (e.g. the wide valley of the Condemios eroded in the Triassic and early Cretaceous mudstones and sands in an area where they are not separated by the most resistant Jurassic limestones, as usually happens in other areas of Guadalajara; Fig. 5). In the second case, heterogeneous or reduced-dimensions landscapes depending on the observation scales are developed (Fig. 3), of this case, there are countless examples distributed along this region.

The strong influence that the characteristics of the stratigraphic successions have on the landscape has not been usually considered. First, deposits of the same age, depending on their different sedimentary rocks, are differently eroded (natural and anthropogenic) originating different landscapes. An example of it in Guadalajara, are landscapes developed on the Miocene detrital facies at the northern and eastem Tajo Basin (unit 6 in Fig. 2). In this case, both areas are composed of horizontal, unfolded, strata eroded by fluviatile processes with a similar agricultural farming. In the eastern area, the Miocene is composed of mudstones, sandstones and conglometares having different resistance to erosion and develops an irregular landscape with strong differences in relief (Fig. 6a). Meanwhile, in the northern area, the Miocene is mainly composed of mudstones, which are much more homogeneous to erosion and develop a low-relief countryside with more homogeneous and smooth landforms (Fig. 6c). As this facies change is ransitional, there are intermediate areas, mainly composed of mudstones with minor sandstone and conglomerate intercalations, where intermediate landscapes develop (Fig. 6b).

Secondly, different rock bodies have different cohesion and resistance to the erosion (soft and hard rocks) that joined to the presence of planar surfaces (stratification and joints), along which erosion usually goes faster originate both characteristic small scale landforms, such as "tormos" in sandstones, "mallos" in conglomerates, etc. (Fig. 3); and an orographic 
(a)

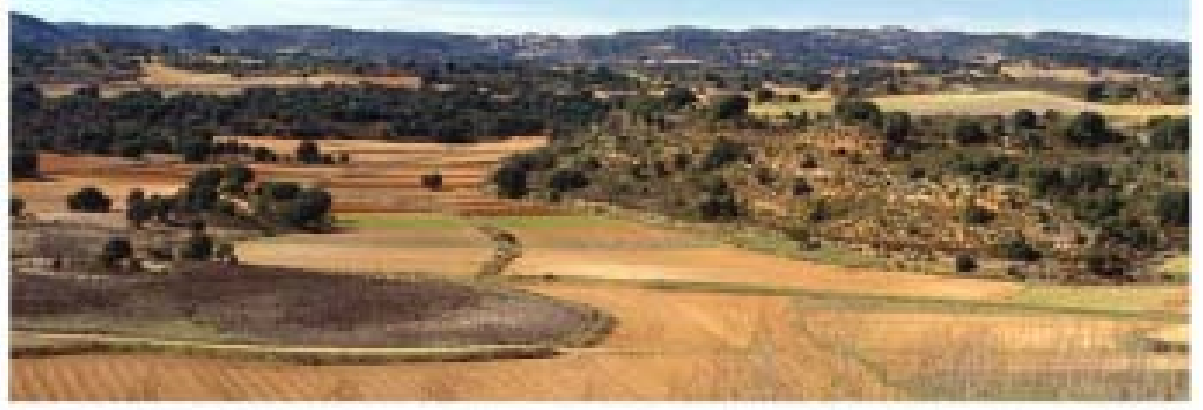

(b)

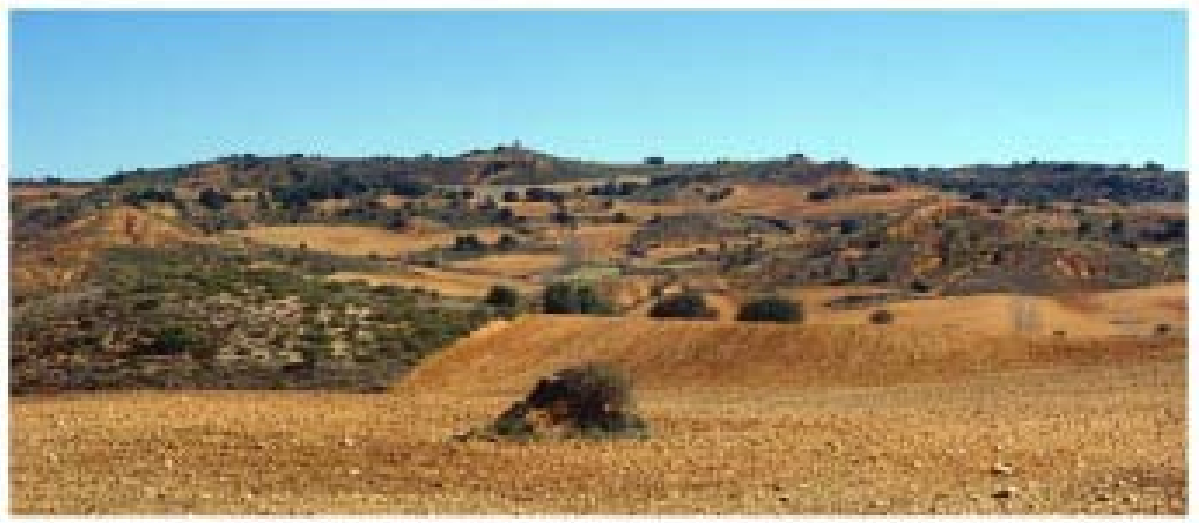

(c)

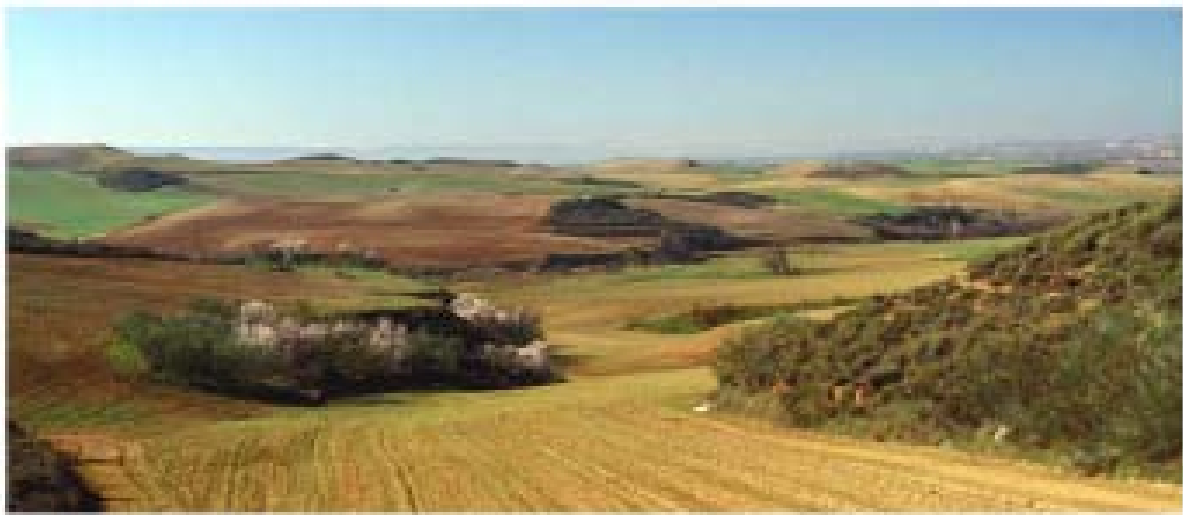

Fig. 6. Three countryside landscapes of Guadalajara developed on unfolded continental Cenozoic sediments (unit 6 in Fig. 2). Up, view of the countryside south of Cifuentes (see Fig. 2 for location), where basin border facies crop out; here consistent rocks predominate (conglomerate and sandstones with calcareous cements), because of this the relief is abrupt and rough, agricultural uses are restricted to the bottom of the ravines and to the plains developed on mudstone areas, being the rest covered for spontaneous vegetation modified by the shepherding and the hunt; cultivated areas are something more than half of the surface. Down, view of the countryside north of Guadalajara city (see Fig. 2 for location), where inconsistent rocks (mudstones) of the basin centre facies predominate, because of this though the relief continues equal of waved, this is smooth; agricultural uses practically cover the entire territory, being the cultivated areas almost $100 \%$ of the territory. Middle, view of the countryside NW of Cifuentes (see Fig. 2 for location), an intermediate geologic composition also gives place to morphology, agricultural uses and landscape of intermediate characteristics as well. 


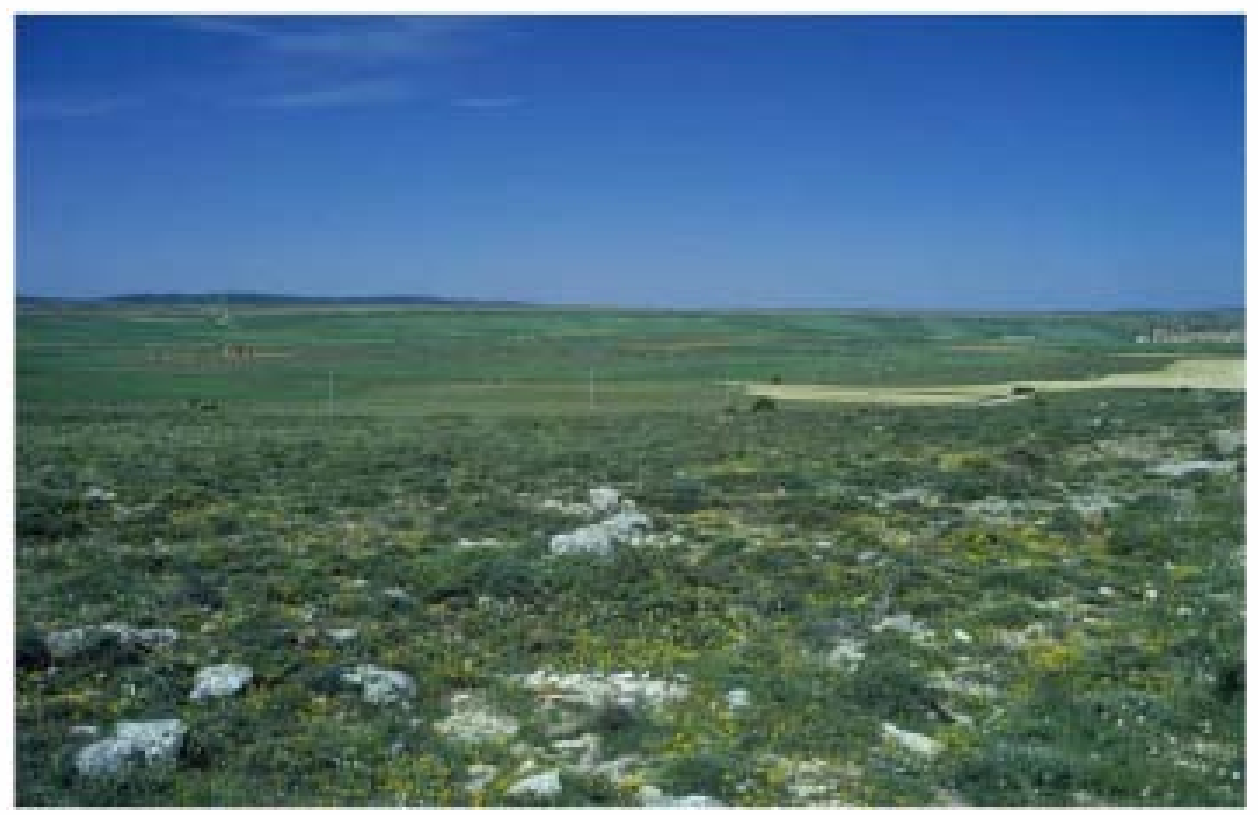

Fig. 7. Irregular plateau west of Maranchón (see Fig. 2 for location) developed on an alternation of lower Jurassic marls (soft) and limestones (hard) formations. Carbonate rocks (foreground) is covered with aromatic shrubs, meanwhile small valleys are eroded into the soft marls (background), and cereal cropping can be developed.

dissimilarity because soft and hard rocks usually alternate in most of the stratigraphic successions.

This orographic difference can be envisaged in landscapes in two forms. On one hand, erosion creates heterogeneous orographies when soft/hard rocks alternate, meanwhile the orography is more homogeneous when soft or hard rock predominate (Figs. 7 and 8); such as the erosive plateaux developed on Jurassic strata of Guadala jara, the lower Jurassic is composed of an alternation of carbonates (hard) and marls (soft) and an incised plateaux with small valleys is developed (Fig. 7), while the upper Jurassic is composed of carbonates lacking marl intercalations and the plateaux eroded are more homogeneous (Fig. 8).

On the other hand, a direct relationship usually exists between the thickness of the regional stratigraphic succession and the thickness of these rock bodies. Thus, in areas where thickness of regional stratigraphic succession is very important (Fig. 3), are also thick rock bodies that compose it; meanwhile in areas of reduced regional stratigraphic successions, rock body thicknesses are also reduced. These thickness differences of the sedimentary successions have a notable influence on the structure of their landscapes, mainly in folded areas, since the differential erosion among the cohesive and not cohesive rock bodies is the origin of most of the spaces and visual basins They are wider in the first case that in the second. This fact is clearly manifested in this region with Triassic and Cretaceous sedimentary successions that notably increase its thickness eastward; in the case of Triassic sediments, the increase in thickness of Keuper facies, one of the "soft" units where valleys are carved, originates wider valleys eastward (Figs. 4 and 5); in the case of the Cretaceous, the thickness increase of hard calcareous units favoured the development of more wild valleys with vertical cliffs.

A third fact is the presence of depositional systems that originate singular accumulative forms (that are usually rare in the landscape). The most characteristic case is reefs, and the better-known example is the Dolomites. In Guadalajara, these type of configurations is represented by the common quatemary calcareous tuffs (e.g. the Puente San Pedro tuff on the Tajo river, the graded valley of the Mesa River, etc.). 


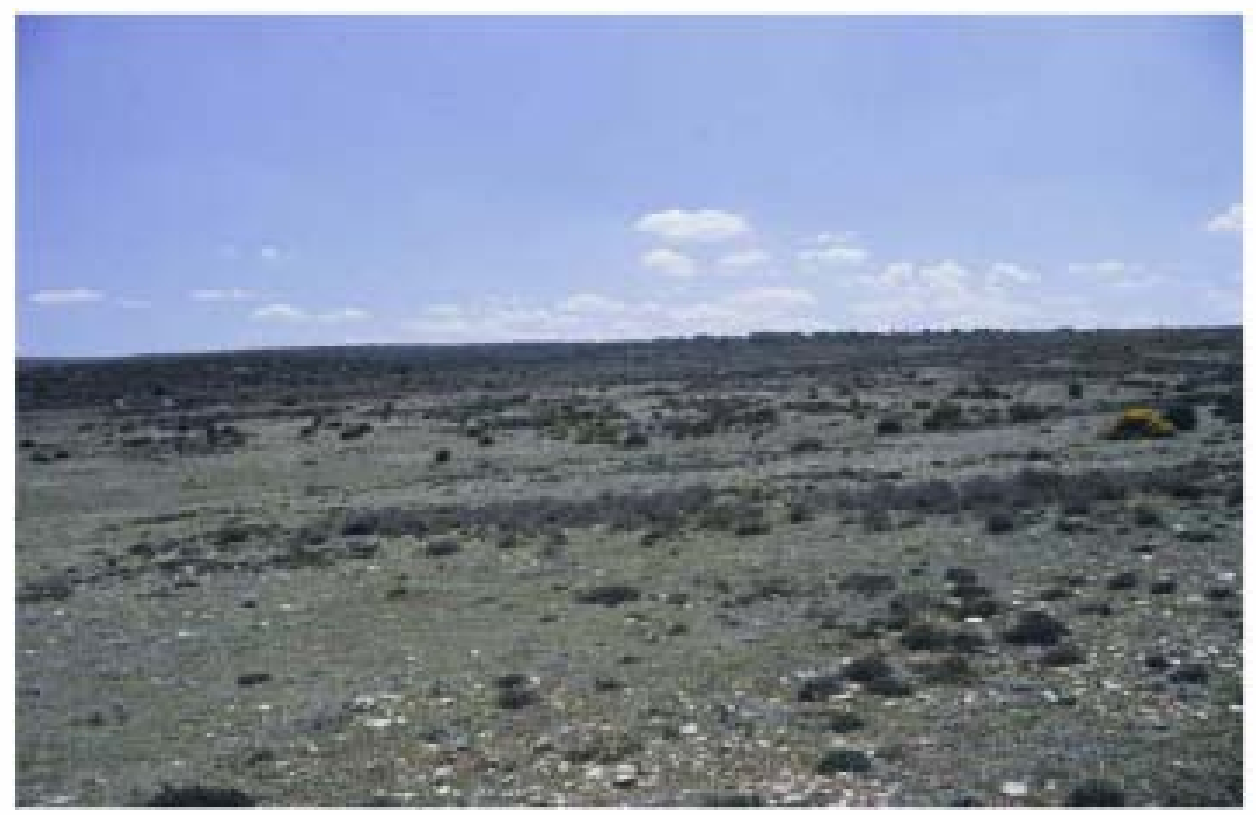

Fig. 8. Regular plateau at Anquela del Pedregal (see Fig. 2 for location) developed on calcareous homogeneous Dogger formations. The absence of marl intercalations originates a more uniform plateau covered with aromatic shrubs.

\subsection{The regional geologic and palaeogeographic domains}

The regional geologic domains correspond to areas with a different geologic history and then different rock structure; therefore they bear differentiated landscapes (Fig. 3). These areas can be termed "Physiographic provinces" (Fenneman, 1916) or "Physiographic regions" (Thornbury, 1965; Hunt, 1967). Physiographic or landscape studies based on geology-geomorphology had a fundamental development in the second half of the 19th century in United States. These studies were strongly influenced for the geo-political situation, in which the population of the East of the United States is launched to colonise the West, and geological studies are an exploratory outpost in order to study the nature and characteristic of the territory (Powell, 1875; Dutton, 1880). During all the 20th century, geology and geomorphology were centred, however, in the study of processes, and the initial physiographic studies remained practically forgotten except in some countries, such as Australia. Presently, the existence of environmental problems, that require the use and sustainable managing of the territory originates that territorial classifications based on geology-geomorphology could be again very useful, perhaps with the only difference that more detailed classifications are needed.

Physiographic provinces or regions are used here to designate first-order forms, such as entire mountain ranges (such as the Central System or the Iberian Ranges) or large sedimentary basins (such as the Tajo Basin) (Fig. 2, left). Then, in the Guadala jara province, all the landscapes in the Iberian Ranges bear such common features that allow their differentiation from those landscapes of the Tajo Basin or the Central System. Physiographic regions are the foundations of the more intuitive, more general and older concept of landscape, in which "land" and "landscape" are related. It is also the landscape concept more frequently used in the literature, as for example the "landscape of Castille" or the "landscape of Brittany".

Extensive entities within a physiographic region constitute second- to third-order forms, having a common geological history but with some ma jor different episodes; these areas are called paleogeographic domains. Such domains, in the Guadalajara province, can be only recognised in the Iberian Ranges. The 
different stratigraphic successions of each domain bearing distinct rock successions originate landscapes with different features (Fig. 3). This fact is clearly envisaged when originally distant domains are joined together, usually due to tectonics. A good example in Guadalajara is the Sierra Pela fault (see Fig. 2 for location), which separates two different areas of the Iberian Ranges; eastward, the Atienza region, presents a very incomplete Mesozoic sedimentary succession (thin Triassic and Cretaceous strata, with absence of Permian and Jurassic strata), meanwhile westward the sedimentary succession is by far much thicker and complete (Permian, and thick, Jurassic, Triassic and Cretaceous). Because of that, the configuration of both territories, and their associated landscapes, is different and their comparison from the Atienza medieval castle is clearly evident.

In these considerations on the lithology of the territory at a great scale, has a major importance the tectonic framework and then, the following section deals with tectonic elements more thoroughly.

\section{Tectonic structure and Guadalajara landscapes}

Tectonic, as lithology and climate, is always present in the landscape. It is always the origin of all the reliefs, and their typology and antiquity are also always recognisable in the landscape. In some areas, further- more, it plays the most important role in the landscape because tectonic processes originate primary landforms and landscapes, such as the Central System in the Iberian Peninsula and in Guadalajara. These landforms make up extensive landscapes whose topography is strongly influenced by the structure of the underlying rocks that have undergone different degrees of deformation and possible associated metamorphism and igneous intrusion. These first order forms can be included in the concept of physiographic regions and that is also a useful means for grouping tectonic regional landforms.

Minor-order tectonic forms also play a role in shaping landscapes, but it is different according to both the scale of observation of landscapes and the tectonic regime of the area (Fig. 9). At medium and small scale, tectonics is only manifested in the landscapes if there is a pronounced lithologic heterogeneity, originating what is known as structural landscapes, such as mesas, cuestas, etc. (Fig. 9), widely described in the literature (Gilbert, 1880; Penk, 1924, etc.) and text-books (Strahler, 1965; Tarbuck and Lutgens, 1999). At a greater scale the things are already different and it is necessary to distinguish those areas of mountain ranges and sedimentary basins (Fig. 9). In mountain ranges, the structural level of deformation controls landscape, meanwhile in sedimentary basin it is the timing of fluvial entrenchment. Two points that have been previously underconsidered in shaping landscapes (Fig. 9).

\begin{tabular}{|c|c|c|c|c|c|c|c|c|}
\hline \multicolumn{9}{|c|}{ TECTONICS $\Rightarrow$ LANDSCAPE } \\
\hline \multirow{4}{*}{$\begin{array}{c}\text { Small and } \\
\text { medium scale }\end{array}$} & \multicolumn{8}{|c|}{ Great and very great scale } \\
\hline & \multicolumn{5}{|c|}{ Mountain Ranges } & \multicolumn{3}{|c|}{ Sedimentary basins } \\
\hline & \multirow{2}{*}{$\begin{array}{l}\text { Upper } \\
\text { structural } \\
\text { level }\end{array}$} & \multirow{2}{*}{$\begin{array}{c}\text { Medium } \\
\text { structural level }\end{array}$} & \multirow{2}{*}{$\begin{array}{l}\text { Lower structural } \\
\text { level (with } \\
\text { cleavage) }\end{array}$} & \multicolumn{2}{|c|}{ Reactivation } & \multirow{2}{*}{$\begin{array}{l}\text { Actives with } \\
\text { sedimentation } \\
\text { / Inactives } \\
\text { without } \\
\text { erosion }\end{array}$} & \multicolumn{2}{|c|}{ Inactives and in erosion } \\
\hline & & & & Epirogenic & Compressive & & Initial erosion & $\begin{array}{l}\text { Avanzed } \\
\text { erosion }\end{array}$ \\
\hline $\begin{array}{c}\text { Structural } \\
\text { landscapes }\end{array}$ & $\begin{array}{c}\text { Complex } \\
\text { structural } \\
\text { landscapes }\end{array}$ & $\begin{array}{l}\text { Litho-Structural } \\
\text { landscapes }\end{array}$ & $\begin{array}{c}\text { Homogeneous } \\
\text { lithologic } \\
\text { landscapes }\end{array}$ & $\begin{array}{l}\text { Landscape } \\
\text { with gorges }\end{array}$ & $\begin{array}{l}\text { Block-faulted } \\
\text { landscapes }\end{array}$ & $\begin{array}{c}\text { Plain and } \\
\text { coastal } \\
\text { landscapes }\end{array}$ & $\begin{array}{c}\text { Simple } \\
\text { structural } \\
\text { landscapes }\end{array}$ & $\begin{array}{c}\text { Rolling } \\
\text { landscapes with } \\
\text { hills }\end{array}$ \\
\hline $\begin{array}{l}\text { Mesas and } \\
\text { cuestas near } \\
\text { Codes }\end{array}$ & $\begin{array}{l}\text { Ridges and } \\
\text { valleys of } \\
\text { 『Alto Talio』 }\end{array}$ & $\begin{array}{l}\text { Sierra del } \\
\text { Robledal }\end{array}$ & $\begin{array}{c}\times \\
\text { [Salamanca] }\end{array}$ & $\begin{array}{c}\times \\
\text { [Ribeira } \\
\text { Sacra] }\end{array}$ & $\begin{array}{c}\times \\
\text { [Alberche } \\
\text { valley] }\end{array}$ & $\begin{array}{l}\text { La Alcarria } \\
\text { mesas (with } \\
\text { minor erosion) }\end{array}$ & $\begin{array}{l}\text { Mesas and } \\
\text { gorges near } \\
\text { Brihuega - } \\
\text { Cifuentes }\end{array}$ & $\begin{array}{c}\text { Hita } \\
\text { countryside } \\
\text { with remanent } \\
\text { hills }\end{array}$ \\
\hline
\end{tabular}

Fig. 9. Relationships between the tectonic structure of the territory and their landscapes. 


\subsection{Mountain range areas}

Compression processes and raising of the Earth's crust allow that more or less deep crustal rocks crop out at the surface. Rocks deformed at different depth usually present different lithological compositions, even if they come from a similar parent material (e.g. the series slate-schist-gneis of metamorphic rocks originate from mudstone metamorphism), and deformation structures (faults near the surface and folds at depth). These zones with different structural features were called "structural levels" by Mattauer (1973). The structural level, in which relief is eroded, is the fundamental landscape parameter in mountain areas. If deep areas of the lower structural level crop out, the relative smoothness of the surface suggests that the underlying rocks are more homogeneous, both lithologic (plutonic and high grade metamorphic rocks, as granites and gneises), and structural (ductile deformation with foliation). Thus, the rocks are rather uniformly hard and so thoroughly deformed that little foliation is expressed in landforms at this scale, favouring the development of homogeneous lithologic landscapes characterised by low rounded ridges and valleys, and having a finer grained topographic texture.

These landscapes are not present in Guadalajara, but they are widely extended along adjacent areas of the Hesperian Massif, where long time erosion and Alpine reactivation, there originates the present main types of landscape structures: (a) Paleogene or even Mesozoic large and old peneplains (Pedraza, 1994) that have remained quite geomorphologically stable since then (e.g. Salamanca, at the W of Spain); (b) smoothly modified peneplains of finineogene and Quaternary age, with a strongly entrenched fluvial network due to a recent regional epirogenic rise (e.g. Galicia, at the NW of Spain, Pagés and Vidal Romaní, 1998); c) strongly reactivated areas during alpine movements originating mountain ranges with a block-faulted relief, plane summits and almost absence of crests (e.g. Guadarrama Mountains, at the centre of Spain, Pedraza, 1994).

If upper areas of the lower structural level crop out, the great regularity and symmetry in the distribution of the tectonic structures and a higher heterogeneity of the rock bodies, favour the generation of regular litho-structural landscapes (Fig. 9), as the "Appalachian" relief. Most of the World areas with these characteristics correspond to the Hercynian orogeny, widely extended along all continental plates, and then, this landscape appears in many continental areas with very similar aspects. The entire Central System of Guadala jara belongs to this tectonic setting (1 in Fig. 2).

Finally, the medium and upper structural levels present a great lithologic as well as structural (folds and faults) heterogeneity, what favors the development of very complex litho-structural landscapes (Fig. 9). In the Mediterranean area, these landscapes are located in the Alpine Ranges and they show great differences from each other. Several tectonic factors have a major influence on the characteristics of the Alpine landscapes: (a) The magnitude of the processes of deformation, that causes that the landscapes of the Alps or the Pyrenees (high mountain relief, glaciar erosion, metamorphic rocks, etc.) are different from Jura or Iberian Ranges landscapes (mid mountain relief, fluvial erosion, sedimentary rocks, etc.); (b) the location of the landscape scenario in each Mountain Range, from the core or axial zones (highest relief, older and more consistent rocks, entrenched valleys, etc.) to the marginal zones (more moderate relief, smooth hills and landforms, presence of plains, etc.). The entire Iberian Ranges of Guadalajara belongs to this upper structural level (2-5, and 8 in Fig. 2) and contains from axial zones (e.g. the Sierra of Aragoncillo, where metamorphic Paleozoic rocks crop out) to marginal areas (e.g. the Sierra of Altomira, composed of folded Cretaceous and Paleogene sedimentary rocks). The landscapes of the Iberian Ranges in Guadalajara present then a great heterogeneity, since lithological factors (see above) are added to tectonic ones.

\subsection{Sedimentary basin areas}

In areas of unfolded sedimentary basins, which in the Iberian Peninsula correspond to the Neogene and Quaternary basins, the more important factor in landscape typology is the age of transition (antiquity) among their active sedimentation stage, as endorheic sedimentary basin, and their erosive stage by the beginning of the exorheic processes.

In actual functional basins, such as coastal plains or interior basins, as can partly be seen in the Gallocanta Lake; plains are their almost exclusive scenery (Fig. 9). In older and already inactive basins, if they are 
in the first erosive stages, simple and tabular (mesas) landscapes are common, with wide plains deeply or slightly cut by entrenched fluvial valleys, as the Alcarria "paramos" (7 in Fig. 2). If erosive processes acted for longer times, and erosion level is more intense, irregular hill landscapes prevail (Fig. 9), with "muelas" and buttes usually present that stand out and characterize these landscapes; there is abundant examples of these landscapes in Guadalajara, developed on Cenozoic sediments (Fig. 6), along the valleys of the most important tributaries in the Tajo river (6 in Fig. 2).

\section{The influence of geologic factors on biotic and anthropogenic elements}

As stated above, in Mediterranean areas, there are three types of genetic components of landscapes that are causally and spatially related to each other. The characteristics of the geotic components impede, limit or favour the qualitative and quantitative development of vegetation, either directly or indirectly, through the different agricultural uses. These characteristics of the geotic components also hinder or favour the installation of anthropogenic elements, although historical and cultural factors also have here a remarkable importance.

\subsection{The influence of geotic on biotic components}

In most of the territory of Guadalajara a poor plant cover that is visually almost in balance with the geologic components in the landscape exists (Figs. 7 and 8). The spontaneous plant cover is conditioned, by climatic factors, by the physiographic features of the territory (height, orientation, etc.) and by the properties of geologic substrate (composition, permeability, cohesion, stability, edaphization, etc.). In Guadalajara, the rainfall scarcity and the consequent small soil development enhanced the geologic control on vegetation. Many examples can be mentioned: the specific and poor vegetation developed on gypsum substrates (esparto grass); the low-density of vegetation in areas of cohesive rocks, such as quartzite formations (Valverde de los Arroyos; Fig. 2); the absence of vegetation in the unstable areas due to existence of active geologic processes, such as gullies, screes, etc. In some cases, geologic control can be so important that are superimposed even to the altitude, as happens with the scarcity of vegetation on the thick and compact calcareous rocks at Muela of Somolinos (Fig. 2).

Nevertheless, the most widespread and important modification in the landscapes is what the man carries out on the plant cover. The breakings, new grounds, clearings, substitutions and reforestation modify the landscapes considerably. Comparing pictures from the beginning and middle 20th century with present ones, the main difference is, in almost all the cases, the increase of the vegetation, due to a decreased pressure of the rural population (González Martín and Rubio Fernández, 2000). Pastures, cerealistic steppes and good part of the deserts of aromatic plants are vegetation formations and landscape textures of anthropogenic origin (Costa Tenorio and Blanco Castro, 2000).

In Guadalajara, those modifications of the plant cover have been carried out during centuries under conditions of low technology, and then, geology has mainly determined the different uses of the territory, as forests, grazing and farming areas, etc. First, the consistency of the rock substrate determines the capacity of a territory to be ploughed (Figs. 6 and 7, cereal cropping on marl, soft, formations and aromatic steppe on calcareous, hard, formations), and secondly, the abruptness of the relief controls its possibilities for the grazing or forest use (Fig. 4, cereal cropping in the valley bottom, and bush and forest on the local relief) In some areas, this relationship is so intimate that it is also used as an approach for tracing geological contacts in the elaboration of the geological maps; one can delineate geologic units better from aerial photographs, following land uses, than in the field.

\subsection{The influence of geotic on anthropogenic components}

Geotic components and factors have influenced the distribution and abundance of anthropogenic elements in past times, but presently, the technological development has made them almost irrelevant. The defensive use of orography, as the pre-Roman "castros" (Cretaceous "muelas" of Maranchón; Fig. 2) or the medieval castles (Cenozoic tabular hills of Jadraque and Hita, Fig. 2; also Pelegrina castle, see Fig. 4) disappeared with the invention of gunpowder; later on, the growth of great villages in the vicinity of the wide and fertile 
valleys (Sigüenza and Molina de Aragón; Fig. 2), was substituted by the development of greater cities related to communication roads and railroads (Guadalajara or Azuqueca; Fig. 2).

Much of the territory of Guadala jara, however, conserves the rural structure described above, inherited from older times, with different social and economic relationships. For this reason in their landscapes there are an accused geologic control on the location and size of villages and cities (orographic defensive conrol); the type and intensity of agricultural and cattlemen uses (cereal cropping in the valley bottom, and bush and forest, for cattle, on the local relief) (Fig. 6); the layout of communications ways (mainly following medieval routes along valleys); and the location and size of some resources exractions; etc.

\subsection{The influence of biotic and anthropogenic on relevance of geotic components}

The vegetation cover, as indicated previously (see above), it is only in visibility/conceal relationship with geotic elements and factors of a landscape. Anthropogenic impacts, as fires, cattle, ploughing, forest cutting, installations of farming, gardening and reforestation, sensibly modify the visual importance of geotic components of a territory in their landscapes.

These activities may directly alter geotic properties, because when modifying the vegetable cover, generally for decrease or even disappearance, it has accelerated many geologic processes, some erosive, as the gullies and others of accumulation, as coastal dunes (Rodríguez Ramírez, 1998), all which have not been sufficiently valued. Also, man's direct action can modify the relief due to excavations and mining accumulations, dams, lineal communication infrasructures (highways and high-speed railroads), urban explanations, etc.

Lastly, in the regions with an intense agricultural activity, and more markedly in the case of the surroundings of the historical villages of Guadalajara, a modelling that does not respond to any natural geologic activity exists that are interpreted as originated by land movements accumulated during centuries of agricultural performances. Humans move huge volumes of soil and rock and can be considered as a first order geomorphic agent, moving earth intentionally (mining and construction) and unintentionally as a product of agriculture (Hooke, 2000). This agricultural modelling has neither been systematically considered, nor studied.

\subsection{The landscapes of the Dulce and Salado river valleys: an example of interrelation among different land factors}

The "complex valleys" landscapes (García-Quintana et al., 2001) of the Sigüenza-Molina of Aragón region (Iberian Ranges) (Fig. 2) are a good examples of these relationships. These complex valleys were originated by Quaternary erosion due to the Salado, Vaderas and other rivers with an orographic structure of wide fertile valleys with small- and mid-size mesas and "muelas" enclosed. Villages are located on the margins of the valleys, toward half hillside, with more abundant and greater size vegetation in their suburbs (Figs. 10 and 11). There is a major change of agricultural use on the hillside, at the same height that the village, which follows a more or less straight and horizontal line. Above that line, there are bushes and aromatic plants, and below cereal cropping. At first sight it does not appear as any geologic element; except for the relief, but the distribution of all the components of these landscapes has a geological explanation.

Above the villages, the rock substratum is composed of Lower Jurassic limestones and brecciated dolostones. This is a consistent and porous formation, with a low-developed soil, that cannot be ploughed, but it is permeable. The probable original oak forest, which presently is recovering in some areas, had to disappear due to the wood use, and because of the lack of agricultural capacity, this land was further dedicated to grazing. The edaphic dryness and the sheep and goats pressure developed aromatic plant vegetation rather the less robust herbaceous vegetation. It is also good land for beehives.

Below the towns the rock substratum is composed of Upper Triassic (Keuper) mudstones and gypsum, which are soft and less permeable sediments and therefore arable. They have been dedicated to extensive cereal cultivation; there are, however, crop rotations with some plots left fallow.

The boundary between both agricultural uses is an approximately straight and horizontal line because the contact between both rock units is an approximately plane and horizontal surface, since these materials are 


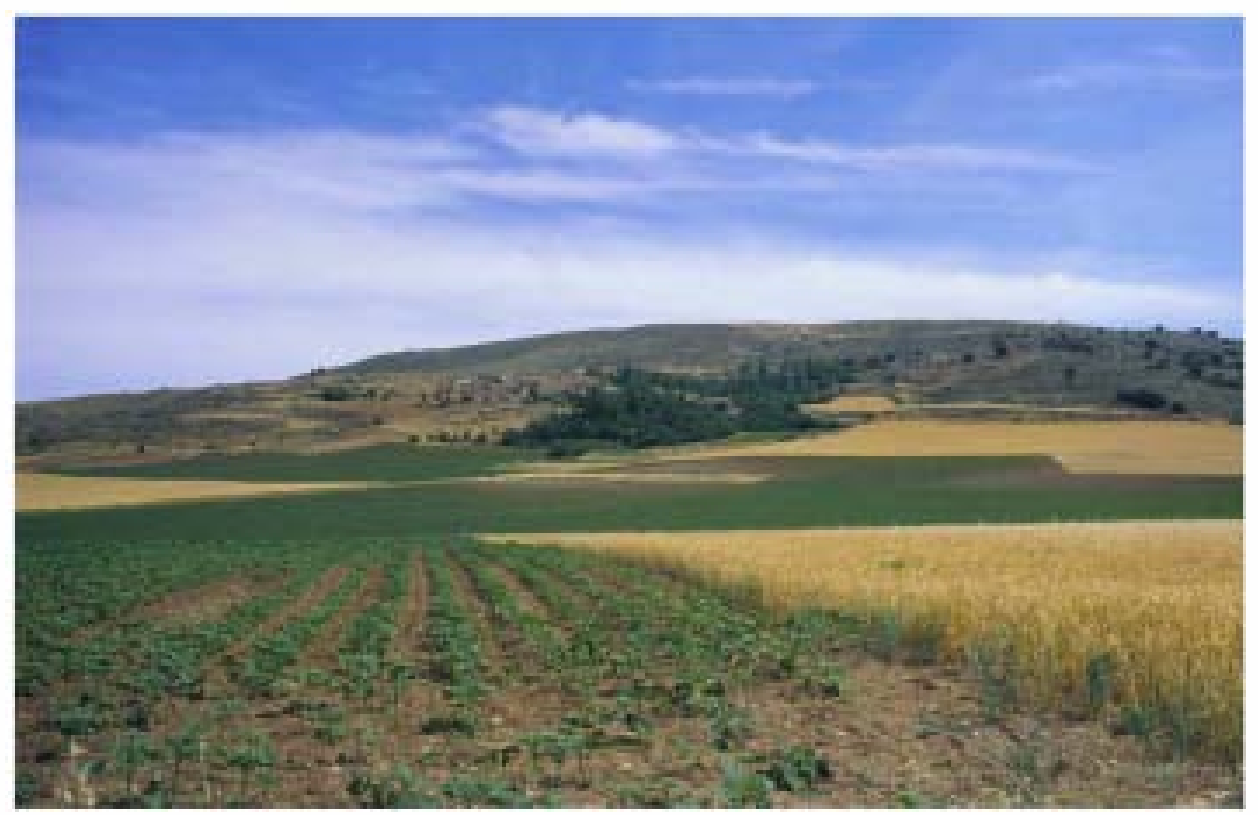

Fig. 10. Bujalcayado village in the Cubillo River valley.

here almost unfolded (the strict reality is a little more complex). This boundary holds a free aquifer with springs in some widely separated points. Village sites are controlled by spring location what is also related to vegetable gardens and leafy forests location. Thus, the villages are equidistantly dispersed along the region, regardless spring orientation in an area of so hard climate like this.

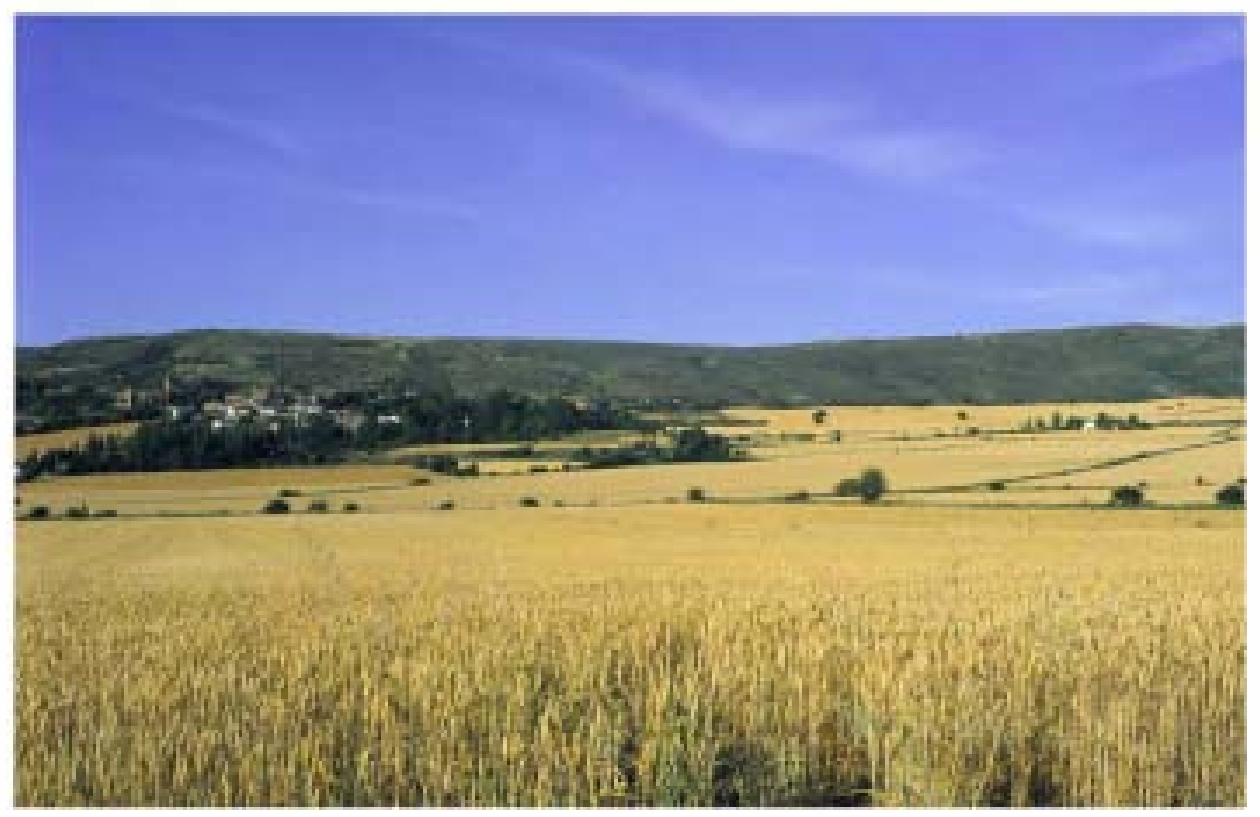

Fig. 11. Cercadillo village in the Alcolea River valley. 
To sum up, the geological composition of a territory influences their landscapes in three ways: (a) being the main responsible of the size and configuration of the scenarios, that is, of the distribution of spaces and of contained elements in the landscape; (b) contributing with rocky elements, by means of forms, textures and colours, as isolated hills and the spectacular colours of the Germanic Triassic; and (c) influencing in the typologies, boundaries, and situation of the biotic and anthropogenic component, and through them, in the elements, textures and colours which the later contribute to the landscape.

\section{Conclusions}

The landscapes of a territory are the consequence of its history. In a territory, the geologic history, the vegetable history and the cultural (human) history, existed and are partly overlapped. Up to now, in the landscape consideration a greater attention to the biological and human history has been paid. On the contrary, less attention has been paid to its geological process stage.

The social and historical development of a territory is reflected in the quantity and range of its anthropogenic elements (Roman roads, bridges and medieval castles, railroads and highways, airports, etc.). This protagonism has not always been territorially coincident and, then, "old" landscapes with inherited structures and elements exist (as those of the previous chapter). Besides, many territories that have never had that protagonism also exist, lacking these social elements and presenting more "natural" landscapes.

The plant cover history, at the Mediterranean domain, is closely related with their human history, because although the plant landscape was partly conditioned by the climatic history, the agricultural uses were so intense and so old that only in some relict areas, vegetation bears races of a different climatic past.

The geological history of a territory has a more independent influence because man cannot modify the geologic factors. If an area has occupied a more central or more marginal position in a Hercynian or Alpine sedimentary basin, it is in tum reflected in their landscapes. If an area has been located in a more internal or more external position of an orogeny, either Hercynian or Alpine, it presents different landscapes. If an area has late erosive phases under glacial or arid conditions, that also presents different landscapes. In sum, it is the succession of their sedimentary, tectonic and geomorphologic histories that mainly produces landscape character.

But in the landscape there is not just a simple overlapping of these histories, because the consequences of the geological history impact on the later vegetable and human histories of the territory.

Thus, in areas like the Guadalajara province, the geologic composition and the human activities that support such can be considered the primary conditions of landscape configuration of the territory, since both condition the vegetative cover and the later barely have influences on them. Both condition the typologies, distribution and relative importance of the geotic, biotic and anthropogenic components of landscapes. A complex network of interrelations among all them exists but, in the base of which lies the geological composition of the territory, included relief, because man and present vegetation usually have very little influence. On the contrary, geology influences, conditions and even limits, the presence, typologies and development of the biotic and anthropogenic elements.

Then, the landscape studies of a territory, at least in the so-called "geological" and "intermediate" landscapes, must always begin with the identification of its geologic factors. It will allow us to better perceive, understand and value the entire landscape, their components and each one of their properties. This way of acquiring a scientific knowledge of landscapes in an applied case, such as the landscapes of Guadalajara province, allows developing a cultural-parimonial classification of the landscapes, with a catalogue of real "landscape types" and a repertoire of specific sites, suitable for their observation. This classification is also useful as resource from social and economic point of views, especially in: (a) environmental management, to know the natural patrimony both for negotiate the uses of the territory and for develop politics of preservation of natural areas; (b) educational policy, to increase the knowledge and esteem of the territory, and to promote more and better activities in the nature; and finally, (c) economic policy, to facilitate the uses and sustainable development of the territory, and even to promote the natural and cultural tourism. Besides, for environmental impact assessment, the detailed and precise knowledge of landscape based in their geological factors, in many cases, can help to 
better characterize the natural sensitiveness and carrying capacity with respect of different kind of impacts.

\section{Acknowledgements}

We are very appreciated to Andrew D. Godfrey of the U.S. Forest Service (USDA) for his revision of the manuscript; the manuscript has been improved by critical reviews by two unknown referees. Financial and institutional supports for this work have been supported by research Project PB97-1 197 of the DGICYT (Institute of Economic Geology, CSIC-UCM).

\section{References}

Aoki, Y., 1999. Trends in the study of the psychological evaluation of landscape. Lands. Res. 24, 85-94.

Bertrand, G., Berutchachvili, N., 1978. Le Géosysthème ou systhème territoriel naturel. Revue Géographique des Pyrénées et du Sud-Ouest 49, 167-180

Bloom, A.L., 1969. The Surface of the Earth. Prentice-Hall, New Jersey, 152pp.

Bolós, M., Tura, M., Estruch, X., Pena, R., Ribas, J., Soler, J., 1992 Manual de Ciencia del Paisaje. Masson, Barcelona, 273pp.

Burbank, D.W., Printer, N., 1999. Landscape evolution: the interactions of tectonics and surface processes. Basin Res. 11, $1-6$.

Cosgrove, D.E., 1998. Social Formation and Symbolic Landscape University of Wisconsin Press, Madison, 312pp.

Costa Tenorio, M., Blanco Castro, E., 2000. Los vegetales y el paisaje. Bol. R. Soc. Esp. Hist. Nat. (secc. Geol.) $96(1 / 2)$, $137-153$.

Dutton, C.E., 1880. Report on the Geology of the High Plateaus of Utah, Washington, $307 \mathrm{pp}$.

Fenneman, N.M., 1916. Physiographic divisions of the United States. Ann. Assoc. Am. Geographers, VI (Plate 1), 1898.

García-Quintana, A., Martín-Duque, J.F., González-Martín, J.A., García-Hidalgo, J.F., Pedraza, J., Herranz, P., Rincón R., Estévez H., 2001. The use of Geology in rural Landscapes cataloguing and valuation: the case of Molina de Aragón and Sigüenza region (Guadalajara, Castilla, La Mancha, Central Spain). Science and Technology for the Safeguard of Cultural Heritage in the Mediterranean Basin, Alcalá de Henares.

Gilbert, G.K., 1880. Report on the Geology of the Henry Mountains, Geographical and Geological survey of the Rocky Mountains region, 2nd ed., Washington DC, Government Printing Office, $170 \mathrm{pp}$.

González Martín, J.A., Rubio Fernández, V., 2000. Las transformaciones antrópicas del paisa je de los sistemas fluviales tobaceos del Centro de España. Bol. R. Soc. Esp. Hist. Nat. (secc. Geol.) 96 (1/2), 155-186.

Hooke, R. LeB., 2000. On the history of humans as geomorphic agents. Geology 28 (9), 843-846.
Hunt, C.B., 1967, Physiography of the United States. Freeman, San Francisco, 480pp.

Knight, J., 2000. Geology, glaciation and the development of landscape "character" in Ireland. Geol. Today 16, 148-153.

Mattauer, M., 1973. Les déformations des matériaux de l'ecorce terrestre. Hermann, Paris, $493 \mathrm{pp}$.

Nassauer, J.I., 1995. Culture and changing landscape structure. Landsc. Ecol. 10, 229-237.

Pagés, J.L., Vidal Romaní, J.R., 1998. Síntesis de la evolución geomorfológica de Galicia Occidental. Geogaceta 23, 119-122.

Pedraza, J. de, 1994. El Sistema Central. In: Gutierrez Elorza M (Ed.), Geomorfología de España. Rueda, Madrid, 63-100pp.

Penk, W., 1924. Die Morphologische Analyse. Geogr. Abh. 2, 283

Powell, J.W., 1875. Physical features of the Colorado Valley, I Mountains and Valleys. Popular Sci. Monthly VII, 384-399.

Rodríguez Ramírez, A., 1998, Geomorfología del Parque Nacional de Doñana y su entomo. Min. de Med. Ambiente, Publ. del Org. Aut. Parques Nacionales, 146pp.

Rougerie, G., Beroutchachvili, N., 1991. Géosystèmes et paysages, Amand Colin Ed., Paris, 302pp.

Strahler, A.N., 1965. Introduction to Physical Geography. Wiley. New York, 455pp.

Sochava, V.B., 1972. L'Étude des géosysthèmes. Stade actuel de la Géographie physique complexe. Izvestija Akademii Nauk SSSR, Serija Geografisceskaja 3,18-21. Translate to French by C.L. Rondeau, CNRS Centre de Documentation et cartographie géographique, Paris

Tarbuck, E.J., Lutgens, F.K., 1999. Earth: An Introduction to Physical Geology, 6th ed. Prentice Hall, NJ, 638pp.

Terkenli, T.S., 2001. Towards a theory of the landscape: the Aegean landscape as a cultural image. Lands Urban Plann. 57, 197-208.

Thombury, W.B., 1965, Regional Geomorphology of the United States. Wiley, New York, 609pp.

Thombury, W.B., 1969. Principles of Geomorphology. Wiley, New York, $594 \mathrm{pp}$.

Wright, R.L., 1972. Principles in a geomorphological approach to land classification. Zeitschrift für Geomorphologie 16, 351-373.

Alvaro García-Quintana received to Ph.D. in Sciences (Geology) from Universidad Complutense, Madrid, Spain, in 1975. From 1975 he is professor of the Universidad Complutense. He has conducted several research projects including two on Landscape studies financed by public organizations. From 1996 he teach courses of "Geology of Landscape" and "Landscape and Protected Natural Spaces". He has been president of the Royal Spanish Society of Natural History. His current research profile includes multidisciplinary studies of landscape combining scientific and humanistic research approach.

José F. Gancía-Hidalgo received to Ph.D. in Geology from Universidad Complutense of Madrid, Spain, in 1985. He worked as a researcher in the Institute of Economic Geology (CSIC) from 1986 to 1989 . Since 1989 he has been associated professor and professor at the Alcalá University. He teaches, among other subjects, "Geology of Landscape" for the Environmental Sciences Ph.D. program since 1998. His current research profile includes interdisciplinary landscape studies mainly for mapping purposes. 
Javier Pedraza received his Ph.D. in Geology for the Universidad Complutense of Madrid, Spain, in 1978. From 1980, he is professor of the Universidad Complutense. He teaches courses on "Geomorphology" and "Land-use Planning". He has been president of the Royal Spanish Society of Natural History. His current research profile includes multidisciplinary studies on the relationship between Society and the Physical Environment, either under patrimonial aspects and natural hazards, in which he has conducted several research projects, financed both by public and private organizations. 